\title{
The Influence of Thermal Shocks on the Thermophisics Properties of the Zircaloy-4
}

\begin{abstract}
DANIEL-CONSTANTIN ANGHEL ${ }^{1}$, ANDREEA ELENA ROSU ${ }^{1}$, GABRIEL NEACSU ${ }^{1}$, IUSTIN-ALEXANDRU POPA ${ }^{1,3}$, MIHAI BRANZEI $^{2}$, VASILE RIZEA ${ }^{1}$, CATALIN-MARIAN DUCU ${ }^{1}$, MARIA MAGDALENA DICU ${ }^{1}$, ALIN DANIEL RIZEA ${ }^{1}$, ELISABETA UNGUREANU1,3, MARIOARA ABRUDEANU1,4*

${ }^{1}$ University of Pitesti, 1 Targu din Vale Str., 110040, Pitesti, Romania

ZUniversity Politehnica of Bucharest, 313 Splaiul Independentei, 060042, Bucharest, Romania

${ }^{3}$ Nuclear Research Institute, 1 Campului, 115400, Mioveni, Romania

${ }^{4}$ Romanian Technical Sciences Academy, ASTR, 26 Dacia Blvd., 010413, Bucharest, Romania

This paper presents the researches on the influence of thermal shocks on the heat transfer properties of the zircaloy-4, now used in fuel element cladding of third generation nuclear reactors. Thermal shock testing was performed using solar energy at high temperatures, up to $1350^{\circ} \mathrm{C}$, with 1,3 and 6 thermal cycles of 60 s. The determination of the thermal diffusivity of the tested samples was made by the flash method at $350^{\circ} \mathrm{C}$, the operating temperature of the third-generation nuclear reactors.
\end{abstract}

Keywords: zircaloy, solar energy, thermal shock, microstructure, thermal diffusivity.

The transition from third generation reactors, in operation today, to a new generation of reactors involves significant researches in the field of materials [1-7]. Romania will build the prototype of the lead cooled fourth generation reactors at the Institute of Nuclear Research, Pitesti - RATEN. The fuel element cladding must provide a long lasting running in contact with the moderator, an efficient heat transfer under normal operating conditions, at $350^{\circ} \mathrm{C}$ for CANDU reactors, and $550^{\circ} \mathrm{C}$ for the lead cooled reactors respectively, and to withstand to temperature variations under running and accident conditions.

The research presented by this paper shows the impact of the heat shock and heat cycles at high temperatures on the microstructure and the thermal diffusivity of the Zy-4 alloy which is used in the construction of the fuel element cladding in the CANDU reactor.

\section{Experimental part}

The tests were performed on Zy-4 alloy samples of a 10 $\mathrm{mm}$ diameter. The chemical composition of the used alloy is $\mathrm{Sn}-1.31 \%$, Fe- $0.20 \%, \mathrm{Cr}-0.11 \%$, the main part being $\mathrm{Zr}$. The mechanical properties of the delivered alloy are as follows: the flow limit is $533.5 \mathrm{MPa}$, tensile strength is 744 $\mathrm{MPa}$ and elongation is $21.25 \%$. In cross-section, hardness has an average value of $228 \mathrm{HV}$, whereas in longitudinal section it has an average value of $258 \mathrm{HV}$. The microstructure of the delivered alloy is polyhedral, the average grain size being of $6.9 \mu \mathrm{m}$ in cross section and of $7.7 \mu \mathrm{m}$ in longitudinal section (fig.1).

Thermal fatigue tests were performed in the PROMES Solar Furnace at Odeillo - Font Romeu, France [8], on cylindrical samples with a $10 \mathrm{~mm}$ diameter and a $8 \mathrm{~mm}$ thickness, through thermal cycles, in the air, with a shock, respectively, three and four successive thermal shocks of 30 and 60s.

The specimens were characterized using scanning electron microscopy and EDS, on unprepared samples at the surface and in the cut section, after mechanical preparation and attack with a $45 \% \mathrm{HNO}_{3}, 45 \% \mathrm{H}_{2} \mathrm{O}$-i $10 \%$ $\mathrm{HF}$ solution, and determining the thermal diffusivity at $350^{\circ} \mathrm{C}$.

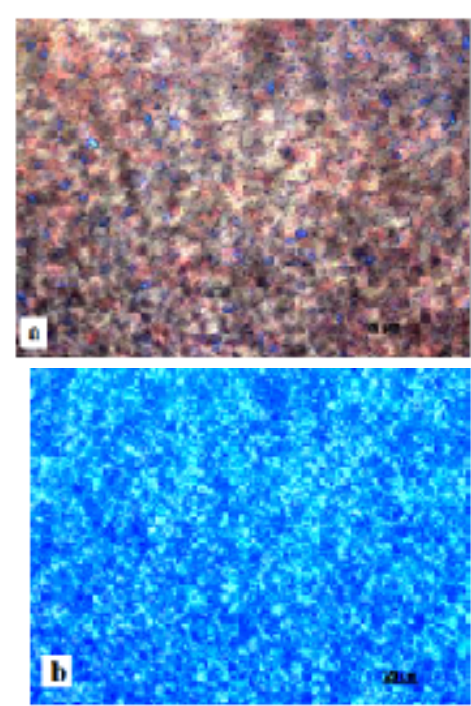

Fig.1 Microstructure of Zy-4 alloy in longitudinal section - $a$ and cross section - $b$

\section{Results and discussions}

The metallographic analysis showed the development of the oxide layers and of the microstructure of the base metal, according to the temperature and the number of thermal shocks.

The surface microscopic analysis showed the microstructure of the oxide layers and the intensification of their degradation process as the temperature of the thermal shocks rises (fig.2. a,b). The rapid growth of the layers at high temperatures leads to high internal tensions resulting in oxide exfoliation which takes place simultaneously with the formation of a new oxide layer. (fig 2c) [9-15].

For the same thermal shock temperature, by increasing the number of the applied thermal shocks, a significant intensification of the surface degradation process was emphasized. (fig. 2a, d).

The section microstructure analysis showed the structure of the oxide layers, the development of their degradation and of the oxide metal interface quality (fig.3).

Under the oxide layers there were evident the structure of the base metal and its changes due to air heating at high temperatures, the formation and the increase of the layers of alpha solid solution stabilized by oxygen dissolution in 

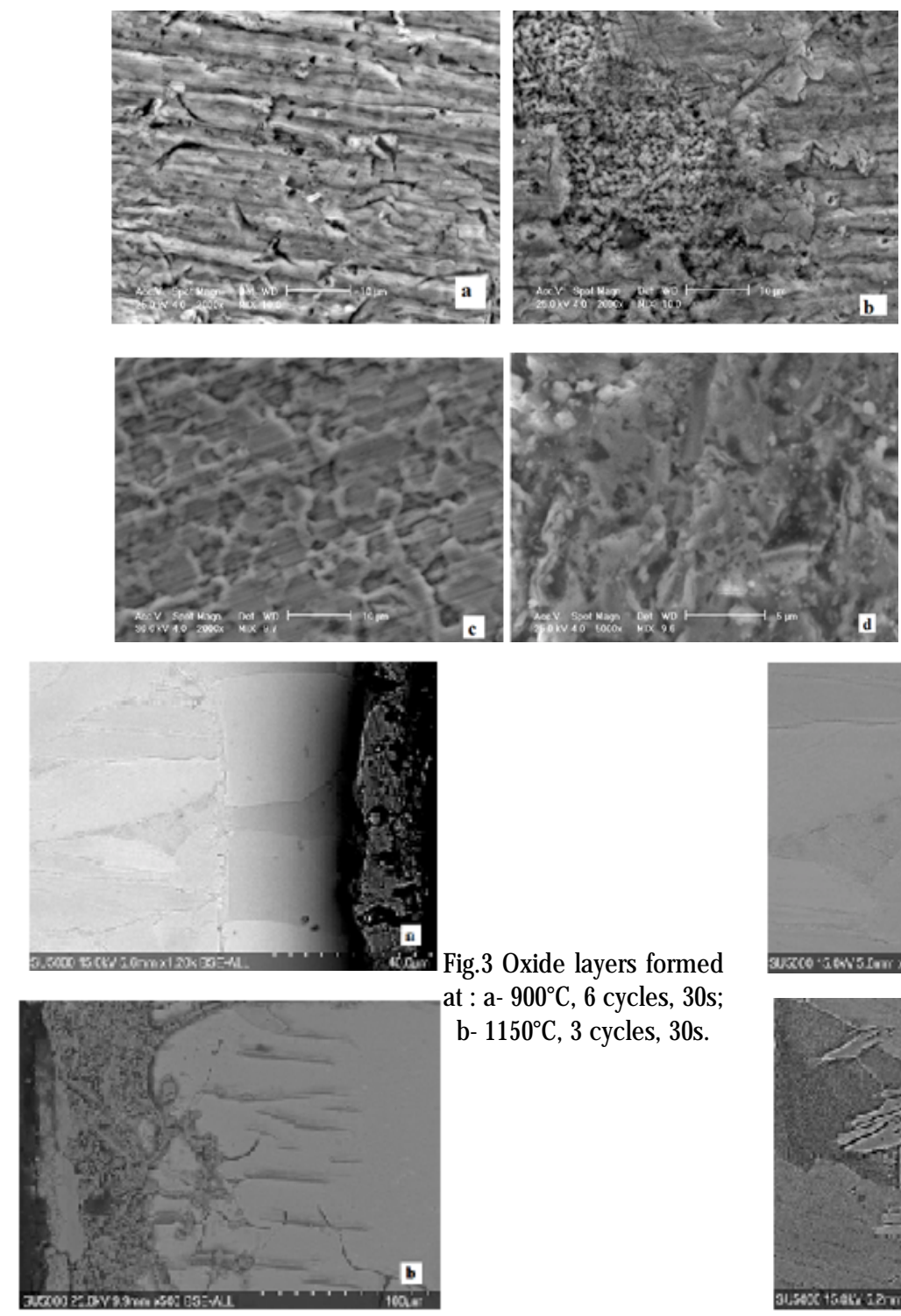

Fig.3 Oxide layers formed at : a- $900^{\circ} \mathrm{C}, 6$ cycles, $30 \mathrm{~s}$; b- $1150^{\circ} \mathrm{C}, 3$ cycles, $30 \mathrm{~s}$.
Fig.2 Surface microscopy of oxide layers formed at different temperatures: for a single thermal shock at $1000^{\circ} \mathrm{C}-\mathrm{a}, 1300^{\circ} \mathrm{C}-\mathrm{b}$ and $1450^{\circ} \mathrm{C}-\mathrm{C}$ and for 6 cycles at $1000^{\circ} \mathrm{C}-\mathrm{d}$. metal under the oxide layer (fig. 3.a, fig.4.a) and the appearance of some needles and plaques structures in the core (fig.4b) which continuously enlarge as the temperature increases.

The degradation of the oxide metal interface through cracks which progress mainly perpendicularly on the interface and the degradation of the oxide layers open new ways of oxygen diffusion and allow for the thickening of the oxide layers and of the alpha solid solution (fig. 5) [1620].

The influence of the thermal shocks and cycles on the thermal diffusivity was determined on samples as thick as 1.9-2 mm. Diffusivity measurements were performed
Fig. 4 Microstructure of the sample tested at $900^{\circ} \mathrm{C}$ with cycles of 60s: a-alpha solution layer and b-core with needles

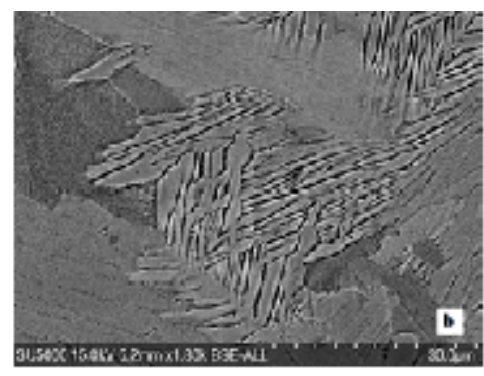
and plaques

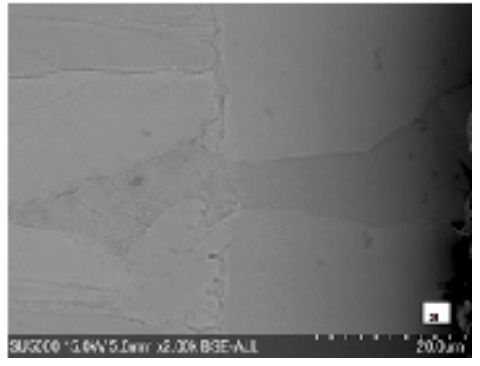

using a FlashLineTM 3000 system which allows the measuring temperature to be programmed at a very close resolution $\left(+0.5^{\circ} \mathrm{C}\right), a \pm 2 \%$ results reproducibility and $\pm 4 \%$ accuracy.

The thermal diffusivity values are correlated with the thermal diffusion of oxygen in the metal and the structural transformations induced by high temperatures [2-3, 2128].

The influence of structural transformations induced by thermal shocks of 60s, whose duration was determined by diffusivity measurements made at CANDU reactor operating temperatures $\left(350^{\circ} \mathrm{C}\right)$, is shown in figure 6.
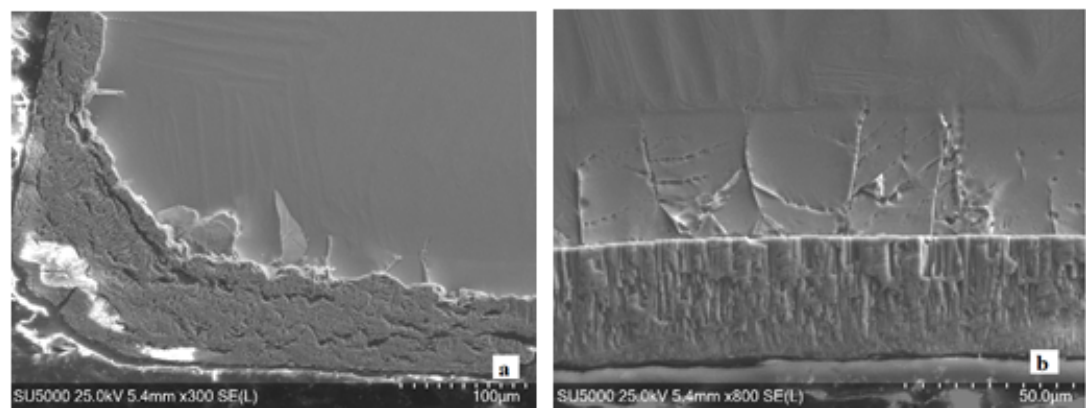

Fig.5 Degradation of the oxide-metal interface at $1000^{\circ} \mathrm{C}$, with the increase in the number of thermal shocks: a-3 cycles, b-6 cycles 


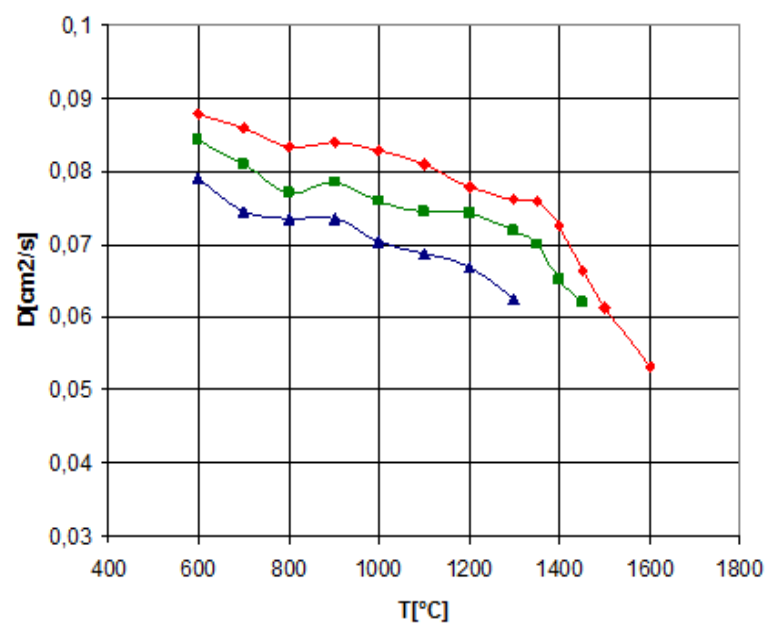

Thermal shock temperature increase leads to diffusivity decrease, a phenomenon associated with grain size increase and with oxide layer degradation processes [ 16, 29].

As the temperature of allotropic transformation is reached, the values of thermal diffusivity present a narrow range of sudden growth, a phenomenon typical of metals in the field of structural transition, which was also emphasized in the case of Zr-Nb alloys [26].

\section{Conclusions}

The zircaloy - 4 specimens were tested to thermal shocks of $60 \mathrm{~s}$, at temperatures up to $1350^{\circ} \mathrm{C}$ and also to cyclic thermal stress of 3 or 6 treatment cycles.

The development of the oxide layers, the structural transformations of the metallic mass and the degradation process of the oxide metal interface were shown.

The diffusivity determinations for the specimens treated with a single thermal shock showed that thermal diffusivity decreases continuously as the shock temperature increases, a phenomenon which can be correlated with the increase of the metal mass grain size $[16,29]$. According to the existing literature, this phenomenon can be correlated with conductivity decrease through the increase of the oxide layer porosity [30].

For cyclic stresses, at the same treatment temperature and duration of the thermal shock, the diffusivity values decrease according to the number of the thermal cycles applied.

Acknowledgment: The thermal shock tests were carried out with funding within the framework of the European program FP7 SFERA II PROMES, Grant Agreement no. 312643, Project TERMOSHOCZY (Influence of structural transformations carried out by thermal shock on thermal diffusivity alloy zircaloy-4) in the PROMES laboratory, at the CNRS Solar Furnace from Odeillo - Font Romeu, France, on the Heliotron plant. We are grateful for our access to European highlevel research resources and for the special support of the PROMES Lab. The doctoral student Popa lustin Alexandru benefited from the scholarship in the POSDRU program through the project PERFORM 1389632014 - Sustainable performance in doctoral and post-doctoral research.

\section{References}

1.***Handbook of Generation IV Nuclear Reactors, Elsevier, 2016 - ch 6 , Lead coled fast reactors.

2.***https://www.atimetals.com/Products/Documents/datasheets/ zirconium/alloy/Zr nuke waste disposal v2.

3.***Nuclear Fuel Behaviour in Loss-of-coolant Accident (LOCA) Conditions, State-of-the-art Report, Nuclear Energy Agency Organisation for economic co-operation and development, nea No. 6846, OECD 2009.
Fig. 6 Variation of thermal diffusivity determined at $350^{\circ} \mathrm{C}$ depending on the temperature and number of shocks of 60 s duration, relative to the untreated sample diffusion

4. ***International Atomic Energy Agency, Nuclear Power Reactors in the World, Reference Data Series No 2, IAEA, Vienna, 2009.

5. ***Issued by the OECD Nuclear Energy Agency for the Generation IV International Forum, Technology Roadmap Update for Generation IV Nuclear Energy Systems, J anuary 2014.

6.***Generation IV Nuclear Reactors: WNA - World Nuclear Association, www.world nuclear.org/.../generation-iv-nuclearreactors.as, May 2017.

7. ***Encyclopedia of Sustainability Science and Technology, Editors: Robert A. Meyer, Nuclear Reactor Materials and Fuels -James S. Tulenko, Springer, 2012.

8. http://www.promes.cnrs.fr. 9. SMIRNOV L., TALUTS S.G., IVLIEV A.D., GORBATOV V.I., POLEV V.F., KORSHUNOV I.G., 55, Issue 3, 2017, p. 380.

10. SETOYAMA D., YAMANAKA S., J. Alloys Compd., 370, no. 1-2, 2004, p. 144-148.

11.COX B., J. Nucl. Mater., 336, Issues 2-3, 2005, p. 331.

12. ABRUDEANU M., ARCHAMBAULT P., 9e Congres International du Traitement Thermique et de I'Ingenierie des Surfaces, Nice, 1994, p. 87.

13.DUMITRESCU, I.M., MIHALACHE, M., ABRUDEANU, M., Rev. Chim.(Bucharest), 66,no.2, 2015, p. 290.

14. DUMITRESCU, I., MIHALACHE, M., DINU, A., MELEG, T., OHAI, D., ABRUDEANU M., Rev.Chim.(Bucharest), 66,no.3, 2015, p. 316.

15. DINU, A., ABRUDEANU, M., Rev.Chim.(Bucharest), 58,no 8, 2007, p.751.

16.ABRUDEANU M., ARCHAMBAULT P., Conference Zr-95, Saclay, France, 1995, p. 303.

17. ABRUDEANU M., ARCHAMBAULT P., PETOT-ERVAS G, PETRESCU N., PETRESCU M., Proceeding of the Second International Conference Held at Selwyn College University of Cambridge, IM- ISBN 0901716502 , 1993, p. 387.

18.LECLERCQ B., These de doctorat Université de Limoge, 2002.

19.MELEG T., OHAI D., ABRUDEANU M., The 2nd International Conferenceon Sustainable Developement trough Nuclear, Reasearch and Education, Pitesti, Romania, IAEA/INISDB-40101636, 2009, p. 73.

20. ABRUDEANU M., PETRESCU N., International Conference of Diffusion and Defects in Solids DD91, Academy of Sciences, MoscouURSS, 75, 1991, p. 84.

21. PARKER, W. J., JENKINS, R. J., BUTLER, C. P., and ABBOTT, G. L., J. Appl. Phys., 9, no. 32, 1979 (1961).

22. WATT, D. A., Br. J. Apply. Phys., 17, 1966, p. 231.

23. LARSON, K. B., and KOYAMA, K., J. Appl. Phys., 38, 1967, p. 465. 24. MICULESCU M., COSMELEATA G., BRANZEI M., MICULESCU F., U.P.B. Sci. Bull., Series B, 70, no. 2, 2008, p.71.

25. CLARK, L. M., III, and TAYLOR, R. E., J. Appl. Phys., 46, no. 714, 1975.

26. KONIGSBERGER E., ERIKSSON G., and OATES W.A., J. Alloys Compd., 299, 2000, p. 148.

27. GLAZOFF M.V.,Idaho National Laboratory UFD Campaign Idaho Falls, Idaho 83415, 2013.

28. LAURENT M., VUILLERMOZ P.-L., Conductivité thermique des solides, Techniques de I'Ingenieur, 1993.

29. ARCHAMBAULT P., ABRUDEANU M., COLLERET B., J. Nucl. Mater, 200, Issue 2, 1993, p. 162.

30. SWAIN M.V., J OHNSON L.F., SYED R., HASSELMAN D.P.H., J. Mater. Sci. Lett., 5, 1986, p. 799.

$\overline{\text { Manuscript received:13.06.2018 }}$ 